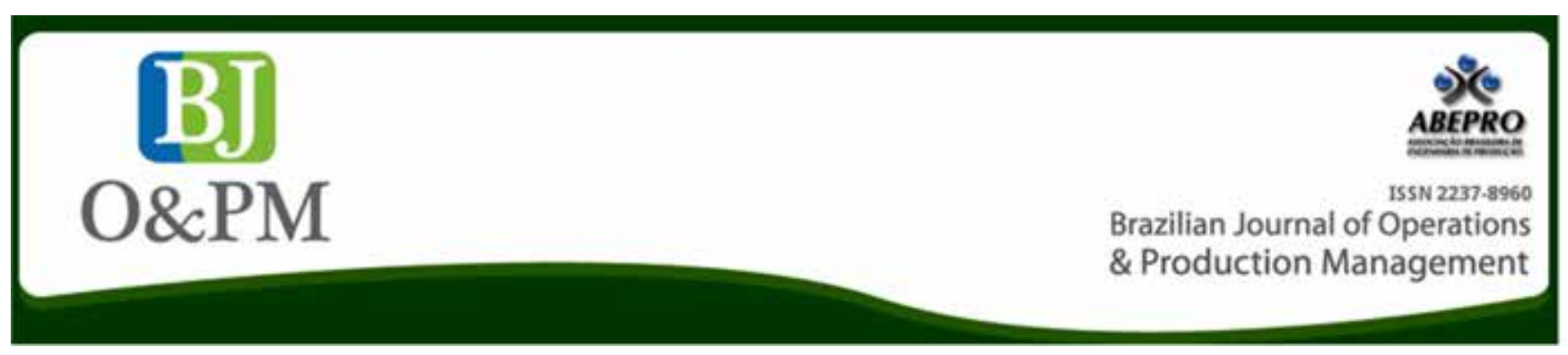

\title{
TOOLS FOR THE STRATEGIC MANAGEMENT OF STAKEHOLDERS IN CIVIL CONSTRUCTION
}

Vânia de Lourdes Marques vanialmarques@gmail.com

Vita Consultoria e Assessoria Ltda

\section{Cid Alledi Filho}

cid.alledi@gmail.com

Núcleo Ético

\section{Fernando Neves Pereira} fnevesp@gmail.com

Centro Federal de Educação Tecnológica Celso Suckow da Fonseca - Cefet-RJ

\begin{abstract}
Highlights: Stakeholder management is an uncommon practice among construction companies in Brazil. There is little availability of appropriate models, guidelines and systematics. The creation of a stakeholder management model for civil construction is important in the current context.

Goal: Contribute to fill the gap of empirical research that generate applicable models in the practices of stakeholder management in the civil construction sector.

Design / Methodology / Approach: Systematic review of the literature was carried out involving the keywords of the research and, using the approach suggested by international standards guidelines, a management model for the management of stakeholders in the construction sector was constructed.

Results: Two products resulted: a) Proposal of a conceptual framework for the management of stakeholders in civil construction, including a strategic and governance level and another with the ventures; b) Systematization of actions for stakeholder management, where the bibliographic content was distributed in stages based on the stakeholder management system proposed by the Standard AA1000SES.

Limitations of the investigation: Difficulties in finding available literature on stakeholder management specifically in the civil construction sector, considering the strategic and governance level.

Practical implications: Provides an innovative system for the strategic and tactical-operational management of stakeholders for the construction sector.

Originality / Value: The research brings important contribution: in the academic area, for the few studies on the subject, especially in Brazil; for companies, it provides an innovative system with the following characteristics: ability to integrate stakeholder management practices between the corporate and project areas; ability to incorporate the experience and learning generated in both environments; applicable to any size of company.
\end{abstract}

Keywords: Sustainable Construction; Stakeholder Management; Stakeholder Theory. 


\section{INTRODUCTION}

The main justification for this paper is linked to the growing importance that sustainability has been given in academia, the business community, and in public opinion. This perception gradually advances on the connections between good practices of social responsibility, and sustainability and business competitiveness (Oliveira, 2013). Stakeholder management takes on an essential role in the strategic deployment of sustainability driven by pressure on corporations to meet the needs and demands of these actors (Freeman and McVea, 2001; Freeman et al., 2004).

Stakeholders are individuals, groups of individuals, or organizations that affect and/or could be affected by the activities of an organization, its products or services, and the performance associated with them (Accountability, 2011). Entrepreneurs and managers should formulate and implement strategic management processes that satisfy the groups that have an interest, claim or right in the organization, extending the growing interest of the companies in managing the stakeholders and integrating their vision into the business (Freeman and McVea, 2001; Freeman et al., 2004).

Civil construction is the human activity with the greatest impact on the environment. Its social and economic impacts are such that they position the sector strategically to serve as a driver for meeting the global targets of sustainable development (Silva, 2003). It is also a large employer of workforce (CBIC, 2014), one of the largest consumers of materials (Leite and Awad, 2012), and a generator of waste (John and Prado, 2010). Civil construction also has an impact on the use of water and energy, on air quality, as well as on labor relations (John and Prado, 2010). The entrance of several companies into the capital markets increases the demand for transparency, availability of information on the production processes, and their environmental and social impacts, among other aspects. The attention given by companies operating in Brazil to non-financial aspects of management is mostly restricted to environmental issues (Silva, 2003) and initiatives linked to unregulated social themes are scarce (Vieira Neto, 2012).

This research was motivated by the possible lack of a structured system for stakeholder management for the construction industry that includes practical approaches to its implementation (Yang et al., 2011). Although there are plenty of theories, there are no strategies, plans, methods or routine processes set up for this purpose (Karlsen, 2002). The analysis of models, guidelines, and processes with these characteristics, found in the literature, and the systematization of these results, contribute to fill this gap. This research includes the high-rise construction sub-sector for the conditions in Brazil, taking into account the building project's life cycle until it starts its operation.

\section{MATERIALS AND METHODS}

The research is qualitative (Minayo et al., 1994) and uses an exploratory and descriptive approach, using literature review, exploratory research, descriptive research, content analysis, and the perspective of the analysts (Santos, 2002; Triviños, 2015). The theoretical basis involves stakeholder management, the stakeholder approach, and the Stakeholder Theory by R.E. Freeman, published in 1984 (Freeman, 2010), together with recent studies in the sector being considered. Figure 1, below, summarizes research method steps and the used approach to enable each of them.

The contents utilized in Steps 1 and 2 (Figure 1) were obtained from identified sources based on keywords. The study highlights 14 articles on stakeholder management models or guidelines, 12 of which are related to civil construction (Figure 2). The objective of these steps was to evidence the importance of the problem, set the stage of theme development and identify guidelines, tools and models already created by the academy so that organizations can manage, in a structured and systematic way, its stakeholders, especially in the civil construction sector.

Step 3 critically reviews all such content, consolidating it in a logical sequence of steps required to manage stakeholders in those companies, considering the theoretical model suggested that will be discussed further in this article.

The main source utilized was the AA1000 Standard. However, the research method also considered other tools to support the analysis of the content and the stakeholder management system proposed, such as GRI and ISO 26000 (ABNT, 2010; GRI, 2013), which, along with the AA1000 standard (Accountability, 2008; Johnston, 2012), has also helped to create the structure for its application.

\section{LITERATURE REVIEW}

\section{A) Civil Construction and Sustainable Construction:}

The human activity that has the most impacts on the environment is civil construction (Silva, 2003). Worldwide it has the following characteristics (Unep, 2014):

- Provides $5-10 \%$ of employment and typically generates $5-15 \%$ of the country's GDP

- Accounts for the greatest use of natural resources, land, and extraction of materials

- Buildings account for $40-45 \%$ of energy consumption (Europe) 


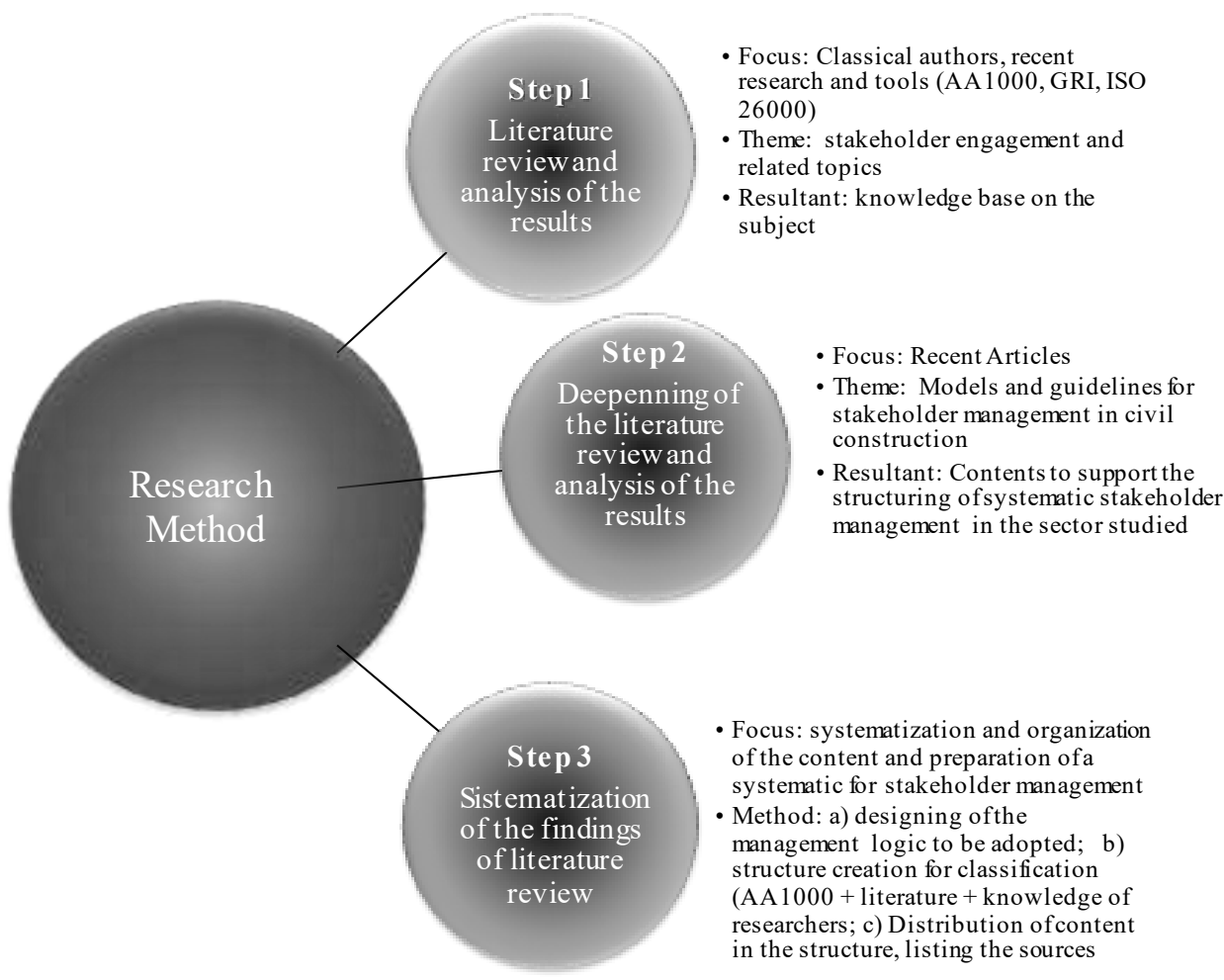

Figure 1. Overview of the Research Method Source: Based on Marques (2013)

\begin{tabular}{|c|c|c|c|c|c|}
\hline $\begin{array}{l}\text { 崫 } \\
\text { 至 }\end{array}$ & $\begin{array}{l}\text { Characterization of the } \\
\text { Construction Sector }\end{array}$ & $\begin{array}{l}\text { Social Responsibility } \\
\text { and Sustainability }\end{array}$ & $\begin{array}{l}\text { Sustainability in } \\
\text { the Construction }\end{array}$ & $\begin{array}{c}\text { Sta keholders' Management } \\
\text { in the Context } \\
\text { of Construction }\end{array}$ & $\begin{array}{c}\text { Models and Guidelines } \\
\text { For the Stakeholders' } \\
\text { Management }\end{array}$ \\
\hline 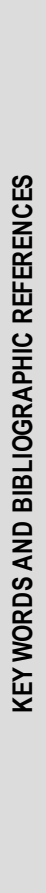 & $\begin{array}{l}\text { The Construction } \\
\text { Sector } \\
\text { - UNEP, } 2012 \\
\text { - CBIC Data, 2014a, b } \\
\text { - Melo and Amorim, } \\
2009 \\
\text { - PMI, } 2014\end{array}$ & $\begin{array}{l}\text { Context, History and } \\
\text { Concepts Evolution } \\
\text { - Hart and Milstein, } \\
2004 \\
\text { - Puppim de Oliveira, } \\
2013 \\
\text { Social Responsibility } \\
\text { and Sustainability in } \\
\text { the Business } \\
\text { Management: } \\
\text { Guidelines and } \\
\text { Models } \\
\text { - Carrol and Bucho tr, } \\
1999 \\
\text { - Lubin and Esty, } \\
2010 \\
\text { - Othman and Mia, } \\
2008 \\
\text { - Paul, } 2008 \\
\text { - ABNT, } 2010\end{array}$ & $\begin{array}{l}\text { Sustainable } \\
\text { Construction } \\
\text { - Bal et al, } 2013 \\
\text { - Rodríguez-Melo, } \\
\text { Mansouri and } \\
\text { - Afshin, } 2011 \\
\text { - Silva, } 2006 \\
\\
\text { Sustainability in the } \\
\text { Construction in } \\
\text { Brazil } \\
\text { - Agopyan and John, } \\
2012 \\
\text { - Silva, } 2006 \\
\text { - Vieira Neto, } 2012 \\
\text { - John and Prado, } \\
2010 \\
\text { Urbanity and } \\
\text { Sustainable Cities } \\
\text { - Leite and Awad, } \\
2012 \\
\text { - UNEP, } 2007\end{array}$ & $\begin{array}{l}\text { Concept, } \\
\text { Stakeholders' } \\
\text { Theory and } \\
\text { Stakeholders } \\
\text { Approach } \\
\text { - Freeman, Whicks } \\
\text { and Parmar, 2004 } \\
\text { - Carrol and Bucholt, } \\
1999 \\
\text { - Freeman and } \\
\text { McVea, 2001 } \\
\text { Implementation and } \\
\text { Tools / } \\
\text { Stakeholders } \\
\text { Management } \\
\text { - Carrol and Bucholt, } \\
\text { 1999 } \\
\text { - Mitchell, Agle and } \\
\text { Wood, 1997 } \\
\text { Series AA 1000 } \\
\text { - Johnston, 2012 } \\
\text { - Accountability, 2008 } \\
\text { e 2011 } \\
\text { GRI Guidelines } \\
\text { - GRI, 2006; 2013a, b } \\
\text { Standard ISO26000 } \\
\text { - Ward, 2011 } \\
\text { - ABNT, 2010 } \\
\text { - Johnston, 2012 }\end{array}$ & $\begin{array}{l}\text { General Application } \\
\text { - Brower and Mahajan, } \\
2012 \\
\text { - Garrod, } 2013 \\
\text { Application to } \\
\text { Construction } \\
\text { - Bal et al, 2013; } \\
\text { - Rodríguez-Melo, } \\
\text { Mansouri and Afshin, } \\
2011 \text {; } \\
\text { - Yang et al 2009; } \\
\text { - Walbaum, Krank and } \\
\text { Teloh, 2010; } \\
\text { - Bourne, 2005; } \\
\text { - Bourne and Walker, } \\
\text { 2006; } \\
\text { - Karlsen, 2002; } \\
\text { - Zhu, Zao and Geng, } \\
\text { 2012; } \\
\text { - Othman and } \\
\text { Abdellatif, 2011; } \\
\text { - Pérez, González-Cruz } \\
\text { and Pastor-Ferrando, } \\
2010 ; \\
\text { - Olander and Landim, } \\
\text { 2005; } \\
\text { - Elias, Cavana and } \\
\text { Jackson, 2002 }\end{array}$ \\
\hline
\end{tabular}

Figure 2. Structure of the Bibliographical Revision, by Key-words. 
Brazilian Journal of Operations \& Production Management

Volume 15, Número 4, 2018, pp. 595-609

DOI: 10.14488/BJOPM.2018.v15.n4.a13
- The construction sector emits more than $40 \%$ of the greenhouse gases on a global level

The strength of the sector in Brazil can be seen in Table 1 below.

Table 1. Evolution of the Added Value of the Construction in Brazil compared to national parameters.

\begin{tabular}{|c|c|c|c|}
\hline & $\begin{array}{c}\mathbf{2 0 1 0} \\
\mathbf{( \% )}\end{array}$ & $\begin{array}{c}\mathbf{2 0 1 1} \\
\mathbf{( \% )}\end{array}$ & $\begin{array}{c}\mathbf{2 0 1 2} \\
\mathbf{( \% )}\end{array}$ \\
\hline Construction/ Brazil - Gross Added Value & 11,6 & 3,6 & 1,4 \\
\hline Brazil - Gross Domestic Product (GDP) & 7,5 & 2,7 & 0,9 \\
\hline Brazil - Gross Added Value & 6,9 & 2,5 & 0,8 \\
\hline
\end{tabular}

Source: CBIC (2014).

The evolution of the sector's Gross Value Added (value that the activity adds to goods and services consumed in the production process) is higher at the current prices than the equivalent national parameters. In 2009, the sector employed 6.9 million people ( $7.12 \%$ of persons employed) in the country.

The sector is based on projects (Rodriguez-Melo and Mansouri, 2011). A project "...is a set of temporary activities carried out in a group so as to produce a product, service or unique result". It has a defined beginning and end, as well as resources and staff. It is not a routine operation, but a set of operations aimed at a specific objective (PMI, 2014). Project management involves the use of knowledge, skills, and techniques in order to obtain effectiveness and efficiency in project execution (PMI, 2014). It requires the following processes: Initiation, Planning, Execution, Monitoring and Control, and Closing. It is comprised of ten areas, including an item on stakeholder management (PMI, 2014). The life cycle stages of a project (Table 2) include an approach of stakeholders.

A construction project is considered sustainable when it reaches the expected performance with minimal negative environmental impact, while meeting the environmental requirements, responding to social and cultural demands, and providing economic improvement (Bal et al., 2013). Efforts in this direction have focused on indicators related to the structural unit in general and to environmental indicators, both globally and in Brazil (Silva and Agopyan, 2003).

Until recently, sustainability was not considered relevant in the environment of the construction business. Several factors have contributed to its evolution in Brazil: the creation of the Brazilian Council for Sustainable Construction (CBCS) in 2007, the dissemination of green building certificates such as LEED and HQE Certification (High Environmental Quality Process), the Vanzolini Foundation, the creation of the "Casa Azul" Seal for Sustainable Construction in 2010 by Caixa Econômica Federal (CEF), and the creation of the PROCEL seal on energy consumption, from Eletrobras. The methods of environmental performance evaluation do not really address the issues related to sustainability indicators and, in general, are not associated with the scale of a highrise building (Silva, 2007).

Table 2. Stages of a Building Project

\begin{tabular}{|c|c|}
\hline PHASES & ACTIVITIES \\
\hline a) Initiation & $\begin{array}{c}\text { Official startup of the project, preparing a } \\
\text { budget and preliminary schedules, drafting } \\
\text { the initial proposal, defining the building } \\
\text { project's team and manager, identifying } \\
\text { the stakeholders. }\end{array}$ \\
\hline b) Planning & $\begin{array}{c}\text { Listing the documents prepared in the } \\
\text { previous phase and developing projects } \\
\text { and prototypes. Finishing the plans of the } \\
\text { building project. }\end{array}$ \\
\hline c) Execution & $\begin{array}{c}\text { Actions and processes to put into practice } \\
\text { the plans drawn up for the project. It in- } \\
\text { volves coordinating people and managing } \\
\text { the project stakeholders. }\end{array}$ \\
\hline Control & $\begin{array}{c}\text { The project's progress and performance is } \\
\text { monitored, analyzed, and organized, and } \\
\text { its results are measured in order to identify } \\
\text { deviations. }\end{array}$ \\
\hline e) Closing & $\begin{array}{c}\text { Finishing all the activities, delivering the } \\
\text { product or service generated, revising and } \\
\text { filing the documents, and demobilizing the } \\
\text { team. }\end{array}$ \\
\hline
\end{tabular}

Source: Based on John and Prado (2010).

\section{B)Social Responsibility (SR) and Sustainability:}

Sustainability is a new "mega trend" in business (Lubin and Esty, 2010), which is a term expressing strong economic and social changes. These "mega trend" changes require managers to adopt a strategic approach, where competitiveness and even the survival of their companies depend on their response to the challenge of sustainability. However, these managers tend to adopt isolated and disjointed actions without considering the whole (Lubin and Esty, 2010; Elkington, 2001). Othman (2008) and Schermerhorn Jr. et al. (2009) defined corporate social responsibility (CSR) as the obligation of an organization to act in a way so as to serve the interests of its stakeholders.

The adoption of the CSR concept has been growing in the business world, including in civil construction, but with few practical results (Sanders and Eskridge, 1993; Loorbach and Rotmans, 2006).

The meaning of the expressions "Sustainable Development" (SD) (or "Sustainability") and "Social Responsibility" (SR) does not have a consensus in academia, in business, 
and in society (Hart and Milstein, 2003). Paul (2008) found that the term most often used by companies to designate their interaction with sustainability was "Sustainability", and after that it was "Social Responsibility" or "Corporate Social Responsibility" or "Responsibility", then "Stakeholder", and, lastly, "Code of Conduct/Behavior".

Paul (2008) showed an inverse relationship between the use of terms derived from "ethics" and "social responsibility", suggesting that the more the managers use them, the more likely they are misleading the public. Contrary to Orlitzky et al. (2011), who point to the increasing number of concepts and terms related to the topic, (Elkington, 2001; Paul, 2008) lean toward its consolidation. For most of the studies, sustainability can become the preferred term in the future, a perspective shared by the authors of this paper.

Lubin and Esty (2010) recommend substituting tactical, random, and isolated approaches for others that are strategic, systematic, and integrated in managing the objectives of sustainability. Hart and Milstein (2003) propose the model of "creating sustainable value for the company," using motivators that will mark out the actions that are needed.

\section{C) Stakeholder Management, Stakeholder Theory, and Stakeholder Approach:}

Stakeholder is "any group or individual who is affected by or can affect the achievement of an organization's objectives" (Freeman and McVea, 2001, p. 4). Stakeholder engagement is an "activity done to create opportunities for dialog between an organization and one or more of its interested parties in order to provide a sound basis for the organization's decisions" (ABNT, 2010, p. 4). Table 3 below summarizes the literature review on the subject, which is later developed with a focus on guidelines and models, especially in civil construction.

"Stakeholder approach" focuses on the management and integration of the relationships and interests of the stakeholders and the company's long-term success. It should be emphasized the active management of the business environment, the relationships involved, and the promotion of common interests (Freeman and McVea, 2001). The strategic management of the stakeholders is the most advanced approach (Freeman and McVea, 2001; Carroll and Buchholtz, 1999) and it means good management, lower risks, and strengthening of the image (Freeman and McVea, 2001; Freeman et al., 2004).

In the case of civil construction companies in general, the issues related to stakeholders are more linked to the characteristics of the product such as on-time delivery, good quality, or some "green" attribute. Although subject to social scrutiny, they do not suffer as much pressure as sectors such as oil and gas and mining. Still they are not immune to the negative effects of a troubled relationship with its stakeholders. The stakeholder approach has an innovative dimension (Hart and Milstein, 2003) and depends on the creation of competencies and skills, generating learning, and new operational routines to support the strategy.

The definition of objectives of organizations should be supported by the stakeholders, upon which depends its long-term success, and the relations with all of them should be worked through by the managers (Freeman and McVea, 2001). The Stakeholder Approach is based on two questions (Freeman et al., 2004):

- What is the purpose of the company? This encourages the managers to create a sense of shared values, bringing the key stakeholders closer together and making it possible to generate an exceptional performance, including the financial result.

- What is the responsibility of the managers with the stakeholders? It urges the managers to express how they want to do business and what kind of relationships they need to create and maintain in order to achieve their purposes.

Concern with the shareholders and with profit should be a result and not the driver of the value creation process. The Stakeholder Theory presupposes that the values are part of the business and rejects the thesis of separation between ethics and economics. The best deal for everyone is the one in which the managers seek to create as much value for the stakeholders as possible, resolving conflicts so that these actors are not compelled to leave the business or to oppose it (Freeman et al., 2004).

Codes, principles, and standards are needed to manage the stakeholders (Leipziger, 2003). Those of greater credibility tend to be those that have already been tested and have been developed with the participation of a wide range of stakeholders. The GRI Guidelines, AA1000, and ISO 26000, used in this study, meet these requirements.

\section{E) The AA 1000 Series:}

It was created by Accountability, which is a global multi-stakeholder network focused on accountability and sustainable development. The following standards are considered for this paper: AA1000APS Accountability Principles Standard and AA1000SES Stakeholder Engagement Standard (Accountability, 2008).

Accountability means "to recognize and take responsibility and be transparent with the impacts from the policies, 
Table 3. Summary of the literature revision about stakeholders - General Vision

\begin{tabular}{|c|c|c|c|}
\hline $\begin{array}{l}\text { CON- } \\
\text { TENT }\end{array}$ & PUBLICATION'S TITLE / THEORETICAL REFERENCE & AUTHOR AND DATE & CONCEPT \\
\hline \multirow{13}{*}{ 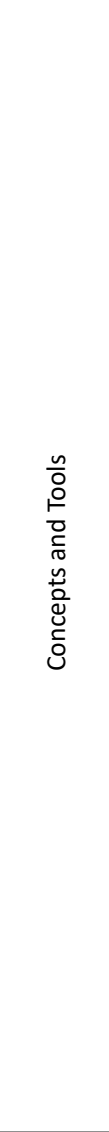 } & $\begin{array}{c}\text { Stakeholder Theory and "The Corporate Objective } \\
\text { Revisited" }\end{array}$ & Freeman and McVea, 2001 & $\begin{array}{l}\text { Theoretical reference and Stakeholders Strategic } \\
\text { Management }\end{array}$ \\
\hline & A Stakeholder approach to Strategic Management & Freeman et al. 2004 & $\begin{array}{c}\text { Theoretical reference and Stakeholders Strategic } \\
\text { Management }\end{array}$ \\
\hline & AA1000 Accountability Principles Standard & Accountability, 2008 & $\begin{array}{l}\text { Stakeholder; Principles for the stakeholder engage- } \\
\text { ment }\end{array}$ \\
\hline & AA1000 Stakeholder Engagement Standard & Accountability, 2011 & $\begin{array}{c}\text { Stakeholder; stakeholder engagement; stakehold- } \\
\text { ers' management }\end{array}$ \\
\hline & $\begin{array}{l}\text { Stakeholder Engagement: Achieving Sustainability } \\
\text { in the Construction Sector }\end{array}$ & Bal et al., 2013 & $\begin{array}{l}\text { Model of stakeholders engagement in construction } \\
\text { projects }\end{array}$ \\
\hline & $\begin{array}{c}\text { Companies in society: sustainability and social } \\
\text { responsibility }\end{array}$ & Oliveira, 2013 & Management with stakeholders \\
\hline & Guidelines GRI 2006 and 2013 & GRI, 2006, 2013 & $\begin{array}{c}\begin{array}{c}\text { Engagement of stakeholders in the sustainability } \\
\text { report }\end{array} \\
\text {. }\end{array}$ \\
\hline & ABNT NBR ISO 26000 & ABNT, 2010 & Concepts, principles and guides \\
\hline & $\begin{array}{c}\text { Driven to be Good: a stakeholder Theory Perspec- } \\
\text { tive (...) }\end{array}$ & Brower and Mahajan, 2013 & $\begin{array}{l}\text { Stakeholders' Theory and Corporate Social Perfor- } \\
\text { mance }\end{array}$ \\
\hline & $\begin{array}{l}\text { Stakeholder Engagement: defining stra- } \\
\text { tegic advantage for sustainable construc- } \\
\text { tion }\end{array}$ & $\begin{array}{l}\text { Rodríguez-Melo and Man- } \\
\text { souri, } 2011\end{array}$ & $\begin{array}{c}\text { Stakeholders engagement as a strategic } \\
\text { advantage }\end{array}$ \\
\hline & Business in society & Oliveira, 2013 & $\begin{array}{l}\text { The theory of stakeholders and CSR: } \\
\text { history, concepts, models, cases }\end{array}$ \\
\hline & $\begin{array}{c}\text { Business \& Society: ethics and stake- } \\
\text { holder management }\end{array}$ & $\begin{array}{l}\text { Carroll and Buchholtz, } \\
1999\end{array}$ & $\begin{array}{c}\text { Model of Social Responsibility and stake- } \\
\text { holders }\end{array}$ \\
\hline & $\begin{array}{l}\text { Corporate Sustainability, Citizenship and } \\
\text { Social Responsibility Reporting: (...) }\end{array}$ & Paul, 2008 & $\begin{array}{l}\text { Stakeholder concept: use by businesses and } \\
\text { perspective }\end{array}$ \\
\hline \multirow{7}{*}{ 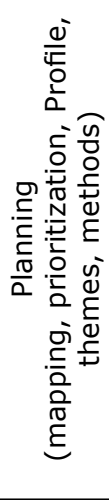 } & AA1000 Stakeholder Engagement Standard & Accountability, 2011 & Engagement planning \\
\hline & GRI Guidelines & GRI, 2006, 2013 & Stakeholder engagement in sustainability reporting \\
\hline & $\begin{array}{c}\text { Stakeholder Engagement: Achieving Sustain- } \\
\text { ability in the Construction Sector }\end{array}$ & Bal et al, 2013 & $\begin{array}{l}\text { Stakeholder management model for construction } \\
\text { projects }\end{array}$ \\
\hline & $\begin{array}{l}\text { Driven to be Good: a stakeholder Theory } \\
\text { Perspective (...) }\end{array}$ & Brower and Mahajan, 2013 & $\begin{array}{l}\text { Stakeholders' Theory and Corporate Social Perfor- } \\
\text { mance }\end{array}$ \\
\hline & Business in society & Oliveira, 2013 & $\begin{array}{l}\text { The theory of stakeholders and CSR: history, con- } \\
\text { cepts, models, cases }\end{array}$ \\
\hline & $\begin{array}{l}\text { Business \& Society: ethics and stakeholder man- } \\
\text { agement }\end{array}$ & Carroll and Buchholtz, 1999 & Social Responsibility Model \\
\hline & ABNT NBR ISO 26000 & ABNT, 2010 & Concepts, principles and guidelines \\
\hline \multirow{4}{*}{ 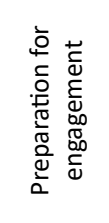 } & AA1000 stakeholder Engagement Standard & Accountability, 2011 & Preparing for stakeholder engagement \\
\hline & GRI Guidelines (G3 e G4) & GRI, 2006, 2013 & Stakeholder engagement in sustainability reporting \\
\hline & $\begin{array}{l}\text { Stakeholder Engagement: Achieving Sustainability } \\
\text { in the Construction Sector }\end{array}$ & Bal et. al, 2013 & $\begin{array}{l}\text { Stakeholder management model for construction } \\
\text { projects }\end{array}$ \\
\hline & ABNT NBR ISO 26000 & ABNT, 2010 & Concepts, principles and guidelines \\
\hline \multirow{4}{*}{ 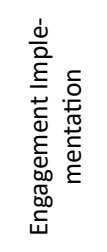 } & AA1000 Stakeholder Engagement Standard. & Accountability & Implementation of engagement \\
\hline & GRI Guidelines & GRI, 2006, 2013 & Stakeholder engagement in sustainability reporting \\
\hline & $\begin{array}{l}\text { Stakeholder Engagement: Achieving Sustainability } \\
\text { in the Construction Sector }\end{array}$ & Bal et. al, 2012 & $\begin{array}{l}\text { Stakeholder management model for construction } \\
\text { projects }\end{array}$ \\
\hline & $\begin{array}{l}\text { Business \& Society: ethics and stakeholder man- } \\
\text { agement }\end{array}$ & Carroll and Buchholtz, 1999 & Social Responsibility Model (Carroll Pyramid) \\
\hline
\end{tabular}




\begin{tabular}{|c|c|c|c|}
\hline \multirow{5}{*}{ 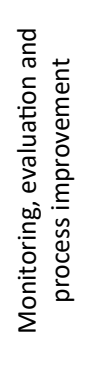 } & AA1000 Stakeholder Engagement Standard & Accountability, 2011 & Monitoring and evaluation of engagement \\
\hline & GRI Guidelines & GRI, 2006, 2013 & $\begin{array}{l}\text { Stakeholder engagement in the sustain- } \\
\text { ability reporting }\end{array}$ \\
\hline & ABNT NBR ISO 26000 & ABNT, 2010 & $\begin{array}{c}\text { Concepts, principles and guidelines on } \\
\text { stakeholders }\end{array}$ \\
\hline & $\begin{array}{l}\text { Stakeholder Engagement: Achieving Sus- } \\
\text { tainability in the Construction Sector }\end{array}$ & $\begin{array}{l}\text { Rodríguez-Melo and Man- } \\
\text { souri, } 2011\end{array}$ & $\begin{array}{l}\text { The stakeholder engagement as a strate- } \\
\text { gic advantage }\end{array}$ \\
\hline & $\begin{array}{c}\text { Driven to be Good: a stakeholder Theory } \\
\text { Perspective }(\ldots)\end{array}$ & $\begin{array}{l}\text { Brower and Mahajan, } \\
\qquad 2013\end{array}$ & $\begin{array}{c}\text { Stakeholders' Theory and Corporate So- } \\
\text { cial Performance }\end{array}$ \\
\hline
\end{tabular}

Source: Based on Marques (2015).

decisions, actions, products, and performance associated with them" (Accountability, 2011), which implies in the stakeholders being involved in identifying, understanding, and giving answers with regard to sustainability. AA1000 APS (Accountability, 2008) presents three principles:

- Inclusion - responsibility with those that cause an impact or that are impacted; implementing a process of stakeholder participation; competencies and resources.

- Relevance - identify the themes of materially relevant sustainability.

- Responsibility - Capacity to respond to issues raised by the stakeholders.

According to the AA1000 Principles, organizations must:

- Set a strategy based on knowledge and the answer to the relevant questions and concerns of its stakeholders;

- Set objectives and standards to support the strategic management and performance;

- Disseminate reliable information linked to these strategies, objectives, standards, and performance for the public who uses it to guide their actions and decisions.

Figure 3 below summarizes the recommendations for applying the Principles.

AA1000 SES provides a structure for the quality of engagement based on the principle of Inclusion. It defines "stakeholder engagement" as the process used by the organization to interact with the relevant interested parties, working toward a particular purpose and to achieve results accepted by those involved (Accountability, 2008). The focus should be the social, environmental, and economic performance in addition to the long-term financial performance through responsible business strategies (Johnston, 2012).

AA1000 recommends including the view of the stakeholders in its policies and integration in governance and in the strategic processes, and being aligned with ISO 26000 in relation to this theme (Johnston, 2012). To include such a view, the following items must be understood: why get involved (the purpose); get involved in what (scope); and who needs to be involved (property, term, stakeholders). The purpose can be strategic and operational. It is important to determinate the material issues related to the business. "A material issue is a matter that will influence the decisions, actions

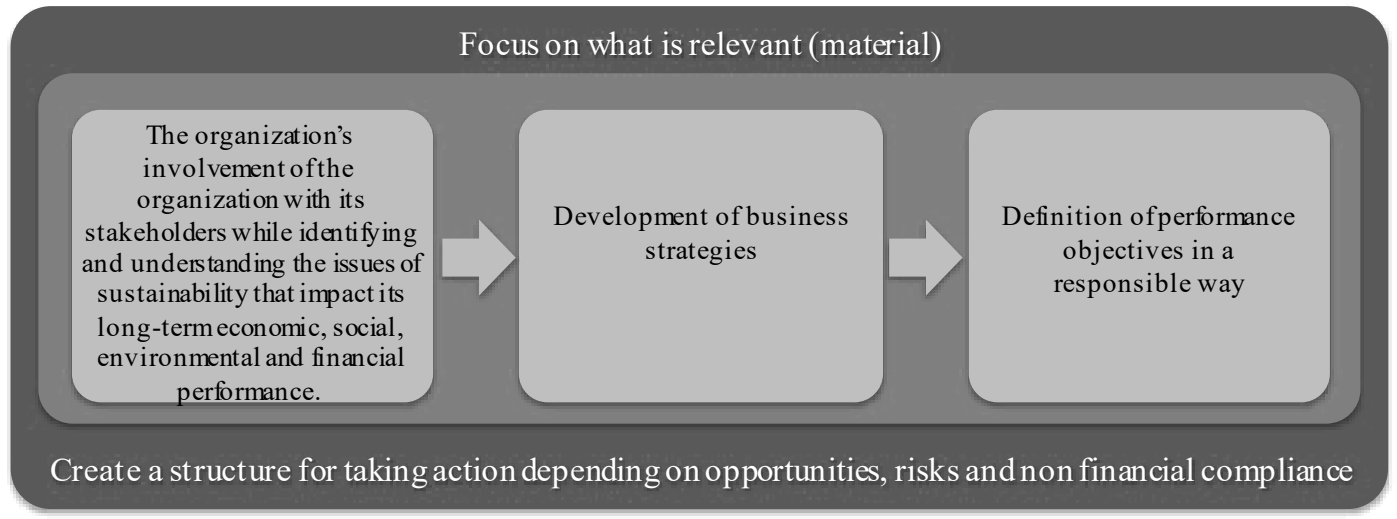

Figure 3 Recommendations for applying the Principles AA1000APS Source: Adapted from Accountability (2008). 
Brazilian Journal of Operations \& Production Management

Volume 15, Número 4, 2018, pp. 595-609

DOI: 10.14488/BJOPM.2018.v15.n4.a13 and performance of an organization or its stakeholders." (Accountability, 2008). The stages of the process are based on the PDCA (Plan-Do-Check-Act) Cycle and the Deming Cycle:

- Plan - mapping of the stakeholders, engagement method, engagement limits, engagement plan, and indicators for the process.

- Prepare - resources, capacity building, contingency plans.

- Implement - invitation to stakeholders and information about the process, documentation and products generated, action plan, communicating the results, and feedback.

- Act, Review, Improve - Monitor and evaluate the quality of the process, learn and improve, give continuity to the action plan, communicate, and report about the engagement.

The Global Reporting Initiative (GRI) is a global multi-stakeholder network (GRI, 2013). Sustainability reports measure and disclose the organizational performance in sustainability. This practice has been increasingly required in organizations in order to bring transparency to the social and environmental aspects of its activities, operations, and decisions. The latest version of the GRI Guidelines is the G4 with two "in accordance" options: Essential and Comprehensive. The first contains essential elements of a report, requiring at least one indicator for each "material" aspect. According to the GRI principle of Stakeholder Inclusion: "The organization shall identify its stakeholders and explain in the report the measures it has taken to meet the expectations and reasonable interests of these parties" (GRI, 2013, p.10).

ISO 26000 is an international standard of guidelines for social responsibility launched in 2010 by International Organization for Standardization (ISO). It aims to promote a common understanding on the practice of social responsibility to guide organizations of any type or size to improve their performance in this area (ABNT, 2010). It makes recommendations and not requirements; it is not based on a Management System (PDCA), neither is it subjected to external verification or certification. It recommends the integration of the socially responsible business behavior through seven social responsibility core themes. It has seven "Sections" (ABNT, 2010) and Section 5 deals with stakeholder engagement.

"Respect for the stakeholders' interests" is one of the seven principles of ISO 26000 (ABNT, 2010).

\section{F) Tools for Building Certification:}

The following initiatives were studied in order to identify the stakeholder management practices present in these tools used by construction companies operating in Brazil:

- $\quad$ LEED - Leadership in Energy and Environmental Design - An international environmental certification and orientation system for buildings, linked to the Green Building Council (GBC), which aims to develop sustainable construction (GBC BRAZIL, 2014);

- HQE Process - High Environmental Quality Certification - It strives for ideal conditions of comfort and health for users. Category 1 - The relationship of the building with the environment that has to do with stakeholder management (Fundação Vanzolini, 2014);

- $\quad$ BREEAM - Building Research Establishment Environmental Assessment Method - Created by the Green Building Council in the United Kingdom, it measures good practices in sustainable construction (BREEAM, 2014);

- CASBEE - Comprehensive Assessment System for Building Environmental Efficiency - Focuses on assessing the environmental performance of buildings (CASBEE, 2013);

- "Casa Azul" Seal - Caixa Econômica Federal - With an environmental focus, it is the first sustainability rating system in civil construction in Brazil (LabEEE, 2014).

While relevant for advancing the sustainability agenda in the sector in Brazil in general, these initiatives have an environmental bias and do not provide structured processes of stakeholder management of the building projects (level of the projects) nor of the companies (corporate level). Because of this, they were not considered in the systematization of the research results.

The articles found with this focus, listed in Figure 2, are briefly presented below. They are the basis for identifying, analyzing, and systematizing the studies with these approaches, especially those produced for civil construction.

Brower and Mahajan Model - Studies the influence of the characteristics of the stakeholders in improving the social performance through the Corporate Social Performance (CSP). The relevance and impact of the demands of the stakeholders about the company are enhanced by several factors, resulting in the increase of CSP measured by more than 35 dimensions of CSR. After analyzing 447 US companies, the 
conclusion reached was that firms that: “(1) have greater sensitivity to stakeholder needs as a result of the firm's strategic emphasis on marketing and/or value creation, (2) face greater diversity of stakeholder demands, and (3) encounter a greater degree of scrutiny or risk from stakeholder action" have a greater breadth of CSP related to their stakeholder landscape (Brower and Mahajan, 2013). The failure to recognize the impacts of stakeholders on results can harm future opportunities.

Garrod Model - It evaluates the potential of stakeholder participation in building mathematical models that include dimensions of sustainability (Garrod et al., 2013).

Model of Bal et al - Applicable to the construction industry, it brings as the key question the existence of a broad spectrum of stakeholders with their own agenda with the possibility of multiple conflicts. It proposes six steps for stakeholder engagement (Bal et al., 2013).

Rodríguez-Melo, Mansouri and Afshin Guidelines - They compare the influence of three factors on the profitability of construction companies in the UK and the relationships between them as revenue generators: government policy of sustainable construction, stakeholder pressure on the company, and attitudes of the managers in relation to sustainability. The main factor was the engagement of the stakeholders, whose influence can account for $20 \%$ of the managerial attitude toward sustainability (Rodríguez-Melo and Mansouri, 2011).

Model of Yang et. al - It proposes guidelines for managing the stakeholders of construction projects in order to provide the teams with a decision-making method based on research gaps: the lack of complete stakeholder management model for the sector and the lack of consolidated practical approaches for this objective. Based on the analysis of the Critical Success Factors, a model was created with four components: 1) Analysis of the stakeholders; 2) Input of information; 3) Decision-making; and 4) Sustainable support. The study finds that there is no uniformity in the behavior of these factors, suggesting different contexts in the projects (Yang et al., 2011).

Model of Walbaum, Krank and Teloh - The authors created an instrument for prioritizing sustainability criteria in the context of sustainable urban development. They used the materiality matrix to identify key issues based on Sustainable Building Tool 07 (SBTool 07) (Wallbaum et al., 2010).

Model created by Bourne and studied by Bourne and Walker - They studied the way of measuring and visualizing the influence of the stakeholders of the projects. The basis was literature, empirical research, and two case studies, utilizing the "Stakeholder Circle ${ }^{T M}$ Tool", created by Bourne.
One of them was in the civil construction sector: "...every project is unique and so are its stakeholders..." (Bourne and Walker, 2006, p. 16).

Karlsen Model - The research aimed to answer the following question: which stakeholders are the most important for a particular project? The customers and end users were considered the most important stakeholders, followed by contractors/suppliers, consultants, grassroots organizations, authorities, media, third parties, control organizations, competitors, unions, and financial institutions. In general, a process of systematic and formal stakeholder management is non-existent, as well as effective strategies, plans, methods, or processes to achieve this objective. Based on this, a sixstep process was proposed: Plan, Identify, Analyze, Communicate, Act, and Monitor (Karlsen, 2002).

Zhu, Zao, and Geng Model - It studies green design practices ("ecodesign") in the construction of apartments in China. The model uses cooperation with stakeholders and customers to improve the environmental, economic, and competitive performance of projects. The results show that the cooperation with customers in general is planned but not really implemented. The authors propose that governments require designers to cooperate with construction stakeholders (Zhu et al., 2012).

Othman and Abdellatif Model - It investigates the role of partnership between government and civil construction professionals in the integration of Corporative Social Responsibility linked to the stakeholders of the project in South Africa (Othman and Abdllatif, 2011).

Guidelines of Pérez, González-Cruz, and Pastor-Ferrando - They analyze the expectations and relationships between the sponsor of the project, the design company, and the contractor. It uses a "Strategy Canvas Tool" to assess the quality of the projects and identify the items related to design and management, and closes with the need for creating mechanisms for managing and sharing this knowledge among the stakeholders (Pérez et al., 2010).

Studies from Olander and Landim - They examine the influence of stakeholders in civil construction projects, in which the negative attitudes of the entrepreneurs toward the stakeholders can create serious obstructions to the execution of the projects. They conclude that the evaluation of the stakeholders' demands is an important step in the planning, implementation, and completion of any project in the area (Olander and Landin, 2005).

The second research by Olander (2006) comprises the analysis of external stakeholders and has the following proposals: identify the stakeholders, give them priority, identify their mission, determine their strengths and weaknesses, 
Brazilian Journal of Operations \& Production Management Volume 15, Número 4, 2018, pp. 595-609

DOI: 10.14488/BJOPM.2018.v15.n4.a13 identify their strategies, foresee their behavior, and implement a stakeholder strategic management.

The third one by Olander and Landin (2008) highlights and compares factors that affect the management processes of the external stakeholders from the perspective of project implementation. It concludes that the project's results depend heavily on the ability of managers to demonstrate the benefits and the negative consequences, with communication being a key factor.

Elias, Cavana and Jackson Guidelines - A case study involving the preparation of a conceptual map of the stakeholders of a highway system, the process for dealing with them, and the transactions to support the project's objectives (Elias et al., 2002). The dynamics of the stakeholders was analyzed from the typology proposed by (Mitchell et al., 1997).

\section{RESULTS}

The proposition of this conceptual system for stakeholder management was based on the premise that organizations need to create structured and strategic ways to manage their stakeholders (Freeman and McVea, 2001). Due to the lack of models applicable to the reality studied, the concepts and assumptions identified in the literature were recommended by Othman and Abdellatif (2011), analyzed critically, while also considering the knowledge and experience of the researchers. This resulted in two products, detailed below: Product 1 - A diagram that aims to provide companies with an overview of the process for promoting dialogue and engagement with their stakeholders (Figure 4); Product 2 - Outlines the steps needed for implementing the management process based on content hierarchy.

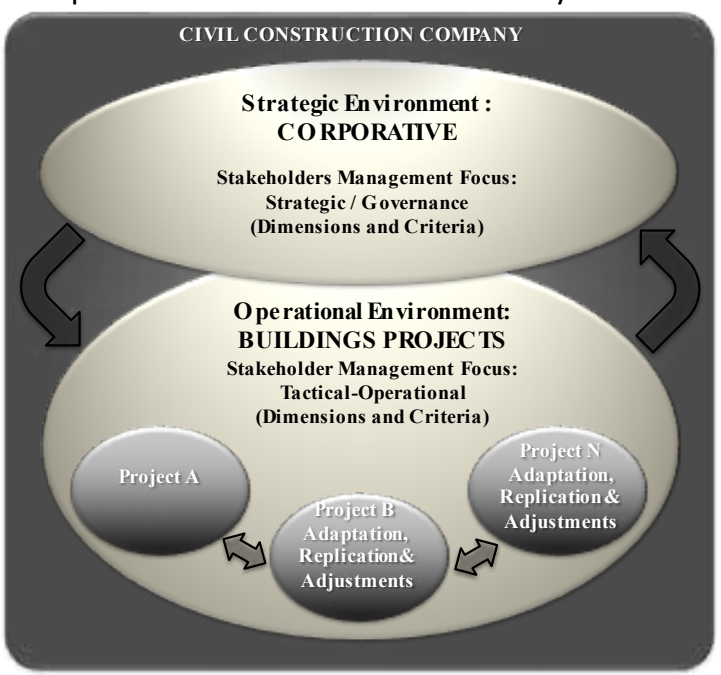

Figure 4. Conceptual System for Stakeholder Management in Civil Construction

Source: By the authors.
The process proposed in Product 1 should have the following characteristics:

- Understand the strategic and governance (corporate environment) level just as much as the building project environment, whose approach is more tactical and operational.

- Emphasize the active management of the business environment, the relationships involved, and the promotion of common interests between the two parties (Freeman and McVea, 2001).

- $\quad$ Provide a general framework and indicate the flows between the corporate and project levels and the interconnections among its other components.

- Reflect the scope of a construction company where the environments represented allow for a full and structured management of stakeholders, ensuring the incorporation of the practice to the organizational and business management model.

- The arrows represent the interconnection between the environments and between projects and will provide learning and the incorporation of results at two levels. The larger ones indicate that the elements identified and prioritized in the process of that context, as well as the results of the engagement and learning generated should be considered and eventually incorporated. The smaller ones represent the connection between projects in terms of exchange of knowledge, experiences, results, and learning.

This element was structured based on the literature, especially on the AA1000 SES Standard whose management system nature provided the proposition of Dimensions and Criteria (Product 2).

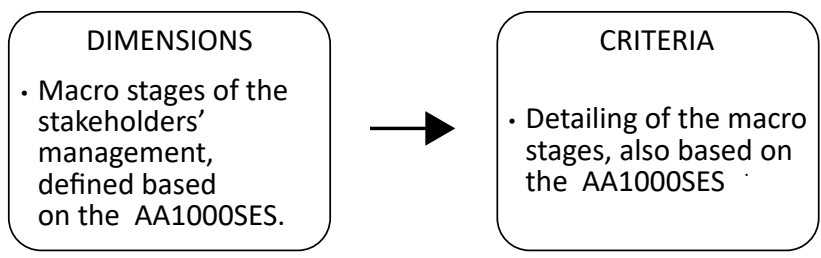

Figure 5. Macro structure of the stakeholder management process.

Source: based on Marques (2015).

The bibliographic content analyzed was systematized from the aforementioned structure for each Dimension and its respective Criteria were created within a logical sequence of stakeholder management. The GRI Guidelines, ISO 26000, articles on stakeholder management models, and to a lesser extent, other references were also considered (Table 4). 
Table 4. Product 2 - Systematization of the stakeholders' management

\begin{tabular}{|c|c|}
\hline \multicolumn{2}{|c|}{ Dimension 1 - Identify the Stakeholders and the Sustainability Themes of the Company/Project } \\
\hline Criteria & Sources \\
\hline $\begin{array}{l}\text { 1.1. Identify the stakeholders (groups and sub- } \\
\text { groups) }\end{array}$ & $\begin{array}{l}\text { Accountability (2011); GRI (2013); ABNT (2010); Yang et al (2011); Bal et al (2013); } \\
\text { Karlsen (2002); Bourne and Walker (2006); Garrod et. al. (2013); Elias et al. (2002); } \\
\text { Mitchell et al., 1997; Carroll and Buchholtz, (1999) }\end{array}$ \\
\hline $\begin{array}{l}\text { 1.2. Promote the business understanding under } \\
\text { the sustainability optic and analyze its impacts, } \\
\text { integrating the stakeholders' interests }\end{array}$ & $\begin{array}{l}\text { ABNT (2010); Bourne and Walker (2006); Olander and Landin, 2005; Accountabili- } \\
\text { ty (2008); GRI (2013); Bal et al (2013); Yang et. al (2011) }\end{array}$ \\
\hline \multicolumn{2}{|c|}{ Dimension 2 - Prioritize Stakeholders and Sustainability Themes } \\
\hline Criteria & Sources \\
\hline 2.1. Prioritize Stakeholders & $\begin{array}{l}\text { Accountability (2011); GRI (2013); ABNT (2010); Carroll and Buchholtz (1999); } \\
\text { Elias et al. (2002); Yang et. al (2011); Oliveira (2013); Bourne and Walker (2006); } \\
\text { Olander (2006); Bal et al (2013); Karlsen (2002) }\end{array}$ \\
\hline 2.2. Determine and Review the Materials Themes & Accountability (2008); GRI (2013); ABNT (2010); Yang et al (2011) \\
\hline 2.3 Establish Indicators & Accountability (2011) \\
\hline \multicolumn{2}{|c|}{ Dimension 3 - Establish and Implement a Process of Stakeholders' Engagement - A - Plan the engagement } \\
\hline Criteria & Sources \\
\hline 3.1 Establish the purpose of the engagement & Accountability (2011); Karlsen, 2002 \\
\hline $\begin{array}{l}\text { 3.2 Review the profile and the prioritization of } \\
\text { stakeholders }\end{array}$ & Accountability (2011); GRI (2013); Bourne and Walker (2006) \\
\hline $\begin{array}{l}\text { 3.3 Determine the level of engagement and meth- } \\
\text { ods to be used }\end{array}$ & Yang et al. (2011); Accountability (2011); GRI (2013) \\
\hline 3.4 Identify the disclosure limits & Accountability (2011) \\
\hline 3.5 Develop an engagement plan & $\begin{array}{l}\text { Accountability (2011); GRI (2013); Bourne and Walker (2006); Elias et al. (2002); } \\
\text { Garrod et al. (2013); Zhu et al. (2012) }\end{array}$ \\
\hline 3.6 Establish indicators & Accountability (2011) \\
\hline \multicolumn{2}{|r|}{ B - Prepare the engagement } \\
\hline Criteria & Sources \\
\hline 3.7 Mobilize resources & Accountability (2011) \\
\hline 3.8. Develop the capacity of engagement & $\begin{array}{l}\text { ABNT (2010); Yang et al. (2011); Yang et al (2011); GRI (2013); Accountability } \\
\text { (2011) }\end{array}$ \\
\hline $\begin{array}{l}\text { 3.9 Identify and prepare oneself for the engage- } \\
\text { ment risks }\end{array}$ & $\begin{array}{l}\text { Accountability (2011); Elias et al. (2002); Bourne and Walker (2006); Olander and } \\
\text { Landin (2008); Bal et al (2013); ABNT (2010) }\end{array}$ \\
\hline \multicolumn{2}{|c|}{$\mathrm{C}-$ Implement the engagement plan } \\
\hline Criteria & Sources \\
\hline 3.10 Invite stakeholders to join in & Accountability (2011); GRI (2013) \\
\hline 3.11 Inform stakeholders about the process & $\begin{array}{c}\text { Karlsen (2002); ABNT (2010); Bal et al (2013); Accountability (2008); GRI (2013); } \\
\text { Olander and Landin (2008) }\end{array}$ \\
\hline 3.12 Engage oneself with the stakeholders & ABNT (2010); Accountability (2011); Yang et al (2011) \\
\hline 3.13 Document the engagement and its results & Accountability (2011); GRI (2013) \\
\hline 3.14 Develop an action plan & Accountability (2011); Bal et al (2013); GRI (2013) \\
\hline $\begin{array}{l}3.15 \text { Communicate the engagement and action } \\
\text { plan results }\end{array}$ & Accountability (2011); GRI (2013); Yang et al (2011); Bal et al (2013) \\
\hline \multicolumn{2}{|c|}{ D - Review and improve the engagement process } \\
\hline Guidelines & Sources \\
\hline 3.16 Monitor and evaluate the engagement & Bal et al (2013); Accountability (2011) \\
\hline 3.17 Learn with the process and improve & ABNT (2010) \\
\hline 3.18 Follow the action plan & Bourne and Walker (2006); Accountability (2011); ABNT (2010) \\
\hline $\begin{array}{l}3.19 \text { Give feedback about the engagement and } \\
\text { prepare report }\end{array}$ & Accountability (2008 and 2011); Karlsen (2002); GRI (2013) \\
\hline
\end{tabular}




\begin{tabular}{|c|c|}
\hline \multicolumn{2}{|c|}{ Dimension 4 - Manage the Learning and Integrate the Results of the Engagement to Strategy and Governance } \\
\hline Criteria & Sources \\
\hline 4.1 Manage the learning & GRI (2013); Accountability (2011); Othman and Mia (2008) \\
\hline 4.2 Integrate the results to governance & GRI (2013); Accountability (2011) \\
\hline
\end{tabular}

Source: By the authors.

The intent was to make sure that the system for civil construction stakeholders would be applicable to any size of the company, could be used both at the corporate and project levels, providing the integration of stakeholder management practices between the two areas, and would allow the incorporation of the experience and learning generated in both levels. Its use should focus on the priority stakeholders and the sustainability themes (materials) that are most relevant for the company, while taking into account its strategy and its context of sustainability.

It is common for the results of an undertaking to be harmed due to errors such as anxiety to bring the project to fruition without giving due attention to defining the problem or to obtaining the necessary information. Human factors are sometimes also ignored and key variables are forgotten in an attempt to simplify a problem. Measures such as adopting models can assist in making decisions, as long as they are used properly (Stevenson, 1981). Crozatti (1998) highlights the importance of developing the organization's management model. Since it consists of the rules and principles that guide managers in identifying the best alternatives for reaching their mission, it impacts all other systems. For the stakeholder management focused on sustainability to become part of the business, models, guidelines, or deployment systems should be a part of the management model. This should give the organization the flexibility it needs to cope with a changing environment.

Considering the view of Stevenson (1981) and Crozatti (1998), it can be inferred that construction projects should not disregard the expectations and needs of its stakeholders on the grounds that the building project needs to go forward at any price. It also follows that the correct use of models, guidelines, or appropriate systems becomes a valuable tool to assist in making and implementing decisions both at the project level and at the corporate level.

The system proposed, therefore, has the following elements:

- It includes stakeholder management in the construction area and the managing of these relations at both levels: strategic (corporate) and tactical-operational (projects);

- It enables stakeholder management to become part of the company's management;
- It is focused on the incorporation of sustainability into business;

- In a structured way, it points to the path of a more strategic vision of stakeholder management in the planning and execution of construction activities for the incorporation.

In order to increase knowledge on the subject, further research is suggested to validate the actions proposed and the instrument containing provisions for the implementation of the theoretical model (Dimensions and Criteria outlined in this study) with specialists, in order to detail the necessary actions within each criterion, to test the system proposed in companies from the segment studied, and to do further research on the current state of the stakeholder management practices in construction companies in Brazil.

\section{CONCLUSIONS}

Companies dialoging and engaging with their stakeholders are preconditions for including sustainability in the business. This implies getting to know the persons, entities, or groups to whom the business activity matters, while understanding and managing the connections of this public with the themes and impacts relevant to sustainability. Conceptual frameworks, such as the Theory of Stakeholders [17], constitute a good basis for this work, as well as themes of sustainability based on global benchmarks, such as the ISO 26000 Standard. They should be prioritized and managed based on the company's stakeholder management criteria, such as AA1000 and GRI Guidelines that are the basis of this research.

Civil construction has significant impacts on sustainability, many of them being negative. In Brazil, the high-rise building sub-sector shows lack of progress in this regard. Few are the innovative companies that are usually motivated by quality management, environmental certifications of buildings, and entry into the capital market. Because it is project-based, this sub-sector has a complex nature with multidisciplinary teams, specifications, and strict targets of costs, deadlines, etc. In general, it is not possible to faithfully reproduce the implementation of a building project, which can hamper the dissemination of good practices and the generation of the knowledge generated. 
The research identified little in terms of models or structured guideline that were sufficiently systemized, coherent, and detailed enough for stakeholder management in civil construction, especially in Brazil. It highlighted the following:

- In general, the focus of the models has been on projects, some of them based on methodologies such as that from the Project Management Institute (PMI);

- They tend to consider a restricted spectrum of stakeholders, often directly linked to the project and its immediate interests;

- The main focus is environmental with little social considerations;

- Few include the population of the catchment area, the workers, the community, and others.

- A joint approach that includes the corporate and project perspective is rare;

- Less common still is the integration of these aspects with a predominant focus on projects;

- The instrumental view of stakeholder management prevails, showing little sensitivity to the partnership potential of these actors with the company.

For a company to be able to talk and get engaged with its stakeholders at the corporate and project levels, a "Conceptual Systematic for Managing Stakeholders in Civil Construction Companies" was proposed. It was felt that the company should answer for its impacts and relationships due to its area of influence. Stakeholder management should include governance, strategies and guidelines, but should also be present in the day-to-day activities of the projects. In this sense, the schematic representation of the system expresses its conceptual dimension and its operating dynamics.

The purpose in this study is to explore established concepts and premises as well as pre-existing models, especially those aimed at the construction area. However, the latter case presented scant results. The analysis of bibliographical material and the experience of the authors were relevant elements of the methodology. Another contribution of the research to be achieved through further studies is to set up a structure with a preliminary proposal of guidelines and criteria for applying the system from the systematization of the contents studied.

The research brings an important contribution in academia because of the scant research on the topic, especially in Brazil, and for companies it provides an innovative system for the strategic and tactical-operational management of stakeholders with the following characteristics:

- Ability to integrate stakeholder management practices between the corporate and project areas;

- $\quad$ Ability to incorporate the experience and learning generated in both environments;

- Applicable to any size of the company.

To use it properly, companies should consider that their relations with stakeholders are dynamic and changeable. Thus, the possible methods and approaches for its application should consider at least the following elements: the company's maturity, the staff's knowledge, the characteristics of the stakeholders, and the engagement objectives.

\section{REFERENCES}

Accountability (2008), "AA1000 AccountAbility Principles Standard 2008", available at: https://www.accountability.org/ wp-content/uploads/2016/10/AA1000APS_english.pdf (accessed 10 Jan 2013).

Accountability (2011), "AA1000 Stakeholder Engagement Standard", Final Exposure Draft. Available at: http://www. rs.belgium.be/sites/5015.fedimbo.belgium.be/files/encart/ attachments/index-30.pdf (acesssed 20 Jun 2013).

Associação Brasileira de Normas Técnicas (ABNT) (2010), ABNT NBR ISO 26000 - diretrizes de responsabilidade social, ABNT, Rio de Janeiro.

Bal, M.; Bryde, D.; Fearon, D. et al. (2013), "Stakeholder Engagement: Achieving Sustainability in the Construction Sector", Sustainability, Vol 6, No. 2, pp. 695-710.

Bourne, L.; Walker, D. H. T. (2006), "Using a visualising tool to study stakeholder influence-two Australian examples", Journal of Project Management, Vol. 37, No. 1, pp. 5-21.

Breeam (2014), "Building Research Establishment Environmental Assessment Method", available at: http://www. breeam.org (acessed 15 Jul 2014).

Brower, J.; MAHAJAN, V. (2013), "Driven to Be Good: A Stakeholder Theory Perspective on the Drivers of Corporate Social Performance", Journal of business ethics, Vol. 117, No. 2, pp. 313-331.

Câmara Brasileira da Indústria da Construção - CBIC (2014), Banco de Dados, PIB Brasil e Construção Civil e mariores empresas de construção civil, available at: http://www. cbicdados.com.br/menu/pib-e-investimento/pib-brasil-e-construcao-civil (acessed 15 Jan 2014).

Carroll, A. B. and Buchholtz, A. K. (1999), Business and Society: Ethics and stakeholder management, 3. ed. South- 
Brazilian Journal of Operations \& Production Management

Volume 15, Número 4, 2018, pp. 595-609

DOI: 10.14488/BJOPM.2018.v15.n4.a13
-Western College Publishing, Cincinnati.

Casbee (2013), “Comprehensive Assessment System for Building Environmental Efficiency", available at: www.ibec. or.jp/CASBEE/english/ (acessed 28 Dec 2013).

Crozatti, J. (1998), "Modelo de gestão e cultura organizacional: conceitos e interações", Cadernos de Estudos, No. 18, pp. 01-20.

Elias, A. A.; Cavana, R. Y.; Jackson, L. S. (2002), "Stakeholder analysis for R\&D Project management", R\&D Management, Vol 34, No.2, pp. 301-310.

Elkington, J. (2001), Canibais com garfo e faca, Makron Books, São Paulo.

Freeman, R. E. (2010), Strategic management: A stakeholder approach, Cambridge University Press.

Freeman, R. E. and McVEA, J. (2001), A Stakeholder Approach to Strategic Management, Darden Business School Working Paper No. 01-02.

Freeman, R. E., Whicks, A. C. and Parmar, B. (2004), "Stakeholder Theory and 'The Corporate Objective Revisited'", Organization Science, Vol 15, No. 3, pp. 364-369.

Fundação Vanzolini (2014), available at: http://vanzolini. org.br (accessed 15 Jul 2014).

Garrod, G.; Raley, M.; Aznar, O. et al. (2013), “Engaging stakeholders through participatory modelling", Proceedings of the ICE-Engineering Sustainability, Vol. 166, No. 2, pp. 75-84.

Global Reporting Initiative - GRI (2006), “Diretrizes GRI G3", available at: www.globalreporting.org (accessed $20 \mathrm{Apr}$ 2009).

Global Reporting Initiative - GRI (2013), Diretrizes G4 para Relato de Sustentabilidade: Manual de Implementação, GRI, Amsterdã.

Green Building Council Brasil - GBC Brasil (2014), available at: http://www.gbcbrasil.org.br (accessed 15 Jul 2014).

Hart, S. L.; Milstein, M. B. (2003), “Creating sustainable value", Academy of Management Executive, Vol. 17, No. 2, pp. 56-69.

John, V.; Prado, R. T. A (Coord.) (2010), Boas práticas para habitação mais sustentável, Páginas \& Letras, São Paulo.

Johnston, A. (2012), "ISO 26000: Guiding Companies to Sustainability Trough Social Responsability?", Social Sciente Research Network, Vol. 9, No. 2, pp. 110-117.

Karlsen, J. T. (2002), "Project stakeholder management", Engineering Management Journal, Vol 14, No. 4, pp. 19-24.

LabEEE (2014), Laboratório de Eficiência Energética em Edificações, Manual Selo Casa Azul CAIXA, available at: http:// www.labeee.ufsc.br/projetos/manual-selo-casa-azul-caixa (accessed 15 Jul 2014).
Leipziger, D. (2003), The Corporate Responsibility Code Book, Greenleaf Publishing, Shefield, UK.

Leite, C.; Awad, J. C. M. (2012), “Cidades Sustentáveis, Cidades Inteligentes - desenvolvimento sustentável num planeta urbano", Bookman, Porto Alegre.

Loorbach, D.; Rotmans, J. (2006), Managing transitions for sustainable development, Springer, Netherlands.

Lubin, D. A. ; Esty, D. C. (2010), "The sustainability imperative", Harvard Business Review, Vol. 88, No. 5, pp. 42-50.

Marques, V. L. (2013), "Relatório de Sustentabilidade: situação atual e perspectivas", available at: http://www.bcb. gov.br/pre/boletimrsa/BOLRSA200907.pdf (accessed 15 Dez 2013).

Marques, V. L. (2015), “Modelo para a gestão de stakeholders em empresas de construção civil", Tese de Doutorado em Engenharia Civil, Universidade Federal Fluminense, Niterói-RJ.

Minayo, M. C. S. (Org.) (1994), Pesquisa social: teoria, método e criatividade, Vozes, Petrópolis, RJ.

Mitchell, R. K.; Agle, B. R.; Wood, D. J. (1997), "Toward a theory of stakeholder identification and salience: defining the principle of the who and what really counts", Academy of Management Review, Vol. 22, No. 4, pp. 853-886.

Olander, S. (2006), External stakeholder analysis in construction project management, Lund University.

Olander, S.; Landin, A. (2005), "Evaluation of stakeholder influence in the implementation of construction projects", International journal of project management, Vol. 23, No. 4, pp. 321-328.

Olander, S.; Landin, A. (2008), "A comparative study of factors affecting the external stakeholder management process", Construction management and economics, Vol. 26, No. 6, pp. 553-561.

Oliveira, J. A. P. (2013), Empresas na Sociedade: sustentabilidade e responsabilidade social, 2. Ed., Elsevier, Rio de Janeiro.

Orlitzky, S; Siegel, D. S.; Waldman, D. A. (2011), "Strategic Corporate Social Responsibility and Environmental Sustainability", Business and Society, Vol. 50, No. 1, pp. 6-27.

Othman, A.; Abdellatif, M. (2011), “Partnership for integrating the corporate social responsibility of project stakeholders towards affordable housing development: A South African perspective", Journal of Engineering, Design and Technology, Vol. 9, No. 3, pp. 273-295.

Othman, A.; Mia, B. (2008), "Corporate social responsibility for solving the housing problem for the poor in South Africa", Journal of Engineering, Design and Technology, Vol. 6, No. 3, pp. 237-257.

Paul, K. (2008), “Corporate Sustainability, Citizenship and 
Social Responsibility Reporting: a website study of 100 model corporations", The Journal of Corporate Citizenship, No. 32 (Winter 2008), pp. 63-78.

Pérez, P. B.; González-Cruz, M. C.; Pastor-Ferrando, J. P. (2010), "Analysis of construction projects by means of value curves", International Journal of Project Management, Vol. 28, No. 7, pp. 719-731.

Project Management Institute (PMI) (2014), available at: http://brasil.pmi.org/brazil/AboutUS/WhatIsProjectManagement.aspx (accessed 14 May 2014).

Rodríguez-Melo, A.; Mansouri, S. A. (2011), "Stakeholder Engagement: defining strategic advantage for sustainable construction", Bussiness Strategy and the Environment, Vol. 20, pp. 539-552.

Sanders, S. R.; Eskridge, W. F. (1993), “Managing implementation of change", Journal of management in engineering, Vol. 9, No. 4, pp. 365-381.

Santos, A. R. (2002), Metodologia Científica - a construção do conhecimento, 5. ed., DP\&A, Rio de Janeiro.

Schermerhorn, J. R.; Hunt, J. G.; Osborn, R. (2005), Fundamentos de comportamento organizacional, Bookman, Porto Alegre, 2005.

Silva, V. G. (2007), “Indicadores de sustentabilidade de edifícios: estado da arte e desafios para desenvolvimento no Brasil”, Revista Ambiente Construído, Vol. 7, No. 1, pp. 47-66.

Silva, V. G.; Agopyan, V. (2003), “Avaliação da sustentabilidade de edifícios de escritórios brasileiros: diretrizes e base metodológica", Tese de Doutorado em Engenharia de Construção Civil, Universidade de São Paulo, São Paulo - SP.
Stevenson, W. J. (1981), Estatística aplicada à administração, Harper Row, São Paulo.

Triviños, A. N. S. (2015), Introdução à Pesquisa em Ciências Sociais: a pesquisa qualitativa em educação - o positivismo; a fenomenologia; o marxismo, Atlas, São Paulo.

United Nations Environment Programme - UNEP (2014), "Buildings and Climate change: Status, Challenges and Opportunities. 2007", available at: http://www.unep.fr/shared/publications/pdf/DTIx0916xPA-BuildingsClimate.pdf (accessed 15 Jan 2014).

Vieira Neto, J. (2012), Proposta de um modelo de gestão baseado no gerenciamento do ciclo de vida: um estudo de múltiplo caso aplicado no setor de construção civil avaliando indústrias brasileiras no Estado do Rio de Janeiro, Tese de Doutorado em Engenharia Civil, Universidade Federal Fluminense, Niterói, RJ.

Wallbaum, H.; Krank, S.; Teloh, R. (2010), “Prioritizing sustainability criteria in urban planning processes: Methodology application", Journal of Urban Planning and Development, Vol. 137 , No. 1 , pp. $20-28$.

Yang, J.; Shen, G. Q.; Ho, M. et al. (2011), "Stakeholder management in construction: an empirical study to address research gaps in previous studies", International Journal of Project Management, Vol. 29, No. 7, pp. 900-910.

Zhu, Q.; Zhao, T.; Geng, Y. (2012), “Mediation Effects of Environmental Cooperation on the Relationship between Sustainable Design and Performance Improvement among Chinese Apartment Developers", Sustainable Development, Vol. 20, No. 3, pp. 200-210.

Received: 17 Oct 2018

Approved: 22 Oct 2018

DOI: 10.14488/BJOPM.2018.v15.n4.a13

How to cite: Marques, V. L.; Alledi Filho, C.; Pereira, F. N. (2018), "Tools for the strategic management of stakeholders in civil construction", Brazilian Journal of Operations \& Production Management, Vol. 15, No. 4, pp. 595-609, available from: https://bjopm.emnuvens.com.br/bjopm/article/view/583 (access year month day). 